\title{
Development of metabolic syndrome after bilateral total thyroidectomy despite the L-t4 replacement therapy: A prospective study
}

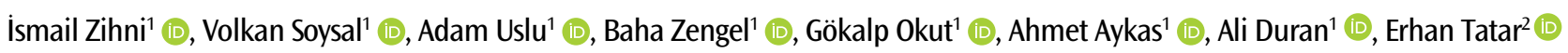

ABSTRACT

ORCID IDs of the authors: i.Z. $0000-0002-2133-2106$; V.S. $0000-0001-8681-5478$; A.U. 0000-0003-2697-472X; B.Z. $0000-0002-1812-6846$; G.0.0000-0002-3641-5625; A.A. 0000-0003-0908-7766; A.D. 0000-0002-2567-5317; E.T. $0000-0002-5068-4231$

Cite this paper as:
Zihni I, Soysal V, Uslu A,
Zengel B, Okut G, Aykas
A, et al. Development of
metabolic syndrome after
bilateral total thyroidectomy
despite the I-t4 replacement
therapy: A prospective study.
Turk J Surg 201834 (3):
178-183.

'Department of General Surgery, Izmir Bozyaka Training and Research Hospital, İzmir, Turkey 2Department of Nephrology, İzmir Bozyaka Training and Research Hospital, İzmir, Turkey

Corresponding Author Erhan Tatar

e-mail: etatar@hotmail.com

Received: 25.10 .2016

Accepted: 29.06.2017

Available Online Date: 28.08.2018

C) Copyright 2018

by Turkish Surgical Association

Available online at

www.turkjsurg.com
Objectives: The literature about the frequency of metabolic syndrome in patients with multinodular goitre and a new onset of metabolic syndrome after total thyroidectomy is limited. The aim of this study was to investigate the effects of total thyroidectomy and thyroid hormones on a new onset of metabolic syndrome in patients who underwent total thyroidectomy and have received thyroid hormone replacement.

Material and Methods: Fifty-nine patients who underwent total thyroidectomy for multinodular goitre were included in this prospective study. Patients' height, weight, and waist circumference were measured, and the body mass index was calculated. Peripheral blood samples were obtained preoperatively and at the $12^{\text {th }}$ and $24^{\text {th }}$ month after total thyroidectomy to examine the lipid profile, glucose homeostasis, and thyroid function tests.

Results: The lipid profile and blood pressure parameters deteriorated, and the mean body mass index and waist circumference with the metabolic syndrome rates significantly increased at the $12^{\text {th }}$ and $24^{\text {th }}$ months follow-up. Preoperative body mass index $(\operatorname{Exp}[B] 1.60 ; p=0.003)$ was independently associated with metabolic syndrome at the $2^{\text {nd }}$ year after total thyroidectomyin a multivariate regression analysis.

Conclusion: The frequency and severity of MetS is high in adult patients with non-toxic multinodular goitre after total thyroidectomy. The frequency of metabolic syndrome increased in patients with a high body mass index after total thyroidectomy.

Keywords: Metabolic syndrome, total thyroidectomy, subclinical hypothyroidism, body mass index

\section{INTRODUCTION}

In the United States, according to the Centers for Disease Control and Prevention report on the National Hospital Discharge Survey 2010, surgical procedures involving thyroid disorders (303.000/year) rank second among the most frequently performed surgical procedures (1). The surgical practice has changed in favor of total thyroidectomy (TT) for the management of benign nodular disease in the last decade. The adherents of TT emphasize its potential advantages of a lower risk for recurrent nodular disease and a lower rate of thyroidectomy for incidental thyroid carcinoma (2-4). On the other hand, when the nodular disease relapse is considered as the primary endpoint in the treatment of multinodular goitre (MNG), two current prospective randomized studies have reported extremely good results with the Dunhill procedure (hemithyroidectomy plus subtotal resection) and demonstrated the safety and efficacy of leaving a small remnant of thyroid tissue without rendering the patient to total thyroid ablation $(5,6)$.

The prevention of metabolic complications after TT is as important as surgery-related complications, and it necessitates a close follow-up and treatment. In general, thyroid hormones regulate the basal metabolism, and by acting directly on carbohydrate and lipid metabolism, they determine the basal metabolic rate and energy expenditure, thus regulating thermogenesis (7-9). Thyroid hormones influence cardiac contractility, the heart rate, and systemic vascular resistance. Triiodothyronine (T3) via its direct effect on the vascular smooth muscle cells leads to vascular relaxation (10). Thyroid hormones increase the activity of lipoprotein-lipase with eventual degradation and utilization of triglyceride substrates. Severe hypothyroidism is usually associated with an increased serum concentration of total cholesterol, low-density lipoprotein-cholesterol (LDL-C), and atherogenic lipoprotein profile represented by increased triglyceride (TGC) and decreased high-density lipoprotein-cholesterol (HDL-C) levels $(11,12)$.

With its growing importance, metabolic syndrome (MetS) is an epidemic public health issue (13). The frequency varies by country, but it ranges between $15 \%$ and $30 \%$ in Europe (14). The main components of MetS are systemic disorders such as insulin resistance-mediated abdominal obesity, glucose intolerance or diabetes mellitus (DM), and dyslipidemia and hypertension. Thyroid hormones and thyroid dysfunction play an active role in nearly all of these components (15). The effect of hypothyroidism on MetS is unclear, and the impact of total thyroidectomy has not been previously examined. In this respect, the thyroxine (T4) replacement therapy to prevent hypothyroidism and to obviate MetS after total TT is a major concern in surgical practice. 
In this study, considering the side-effects of hypothyroidism mentioned above, we investigated the TT and thyroid hormons effects on a new onset of MetS in patients who underwent TT and have received a thyroid hormone replacement therapy. In addition, we aimed to draw attention to the new onset metabolic derangements following the operation.

\section{MATERIAL AND METHODS}

\section{Patients and study protocol}

This prospective study included patients with MNG who had been treated with TT. Sixty-five patients were allocated between October 2011 and July 2014 at the Department of University of Health Sciences, Izmir Bozyaka Research and Training Hospital, Department of General Surgery. The study protocol was approved by the local ethical committee. Informed consent was obtained from all patients. Six patients were excluded from the study for failing to attend regular visits. Analysis of the study was based on the laboratory, demographic and anthropometric data obtained during the preoperative period and at 1 and 2 years after the operation. The T4 replacement therapy was arranged to keep the thyroid-stimulating hormone (TSH) level within the normal range. It was considered that the patients with a TSH value below $4.24 \mathrm{mIU} / \mathrm{mL}$ at the $1^{\text {st }}$ and $2^{\text {nd }}$ year after TT had received effective treatment.

Patients' height $(\mathrm{H})$, weight (W), and waist circumference (WC) were measured and recorded, and the body mass index (BMI) was calculated to assess the patients' body fat. A BMI from 20 to 25 , from 25 to 30 , and over 30 is considered normal, overweight, and obese, respectively. The definition of MetS is based on the National Cholesterol Education Program (NCEP) Adult Treatment Panel III (16). The metabolic syndrome severity score (MetSSS) was calculated using the calculator available at http://publichealth.hsc.wvu.edu/biostatistics/metabolicsyndrome-severity-calculator (17). Patients were considered hypertensive based on double high reading of a systolic blood pressure (SBP) $\geq 140 \mathrm{~mm} \mathrm{Hg}$ and/or a diastolic blood pressure (DBP) $\geq 90 \mathrm{mmHg}$ (18). A clinical diagnosis of hypertension is established if the patient has already been under a treatment program or complied with the above criteria.

The criteria for the diagnosis of diabetes are based on the American Diabetes Association guidelines. Thus, patients with fasting plasma glucose level (FPG) $\geq 126 \mathrm{mg} / \mathrm{dL}$ ( $7.0 \mathrm{mmol} / \mathrm{L}$ ) or $\mathrm{HbA} 1 \mathrm{C} \geq 6.5 \%$, and those with a previous diagnosis of diabetes and/or regularly using antidiabetic drugs were considered to have overt diabetes (19). The homeostatic model assessment (HOMA-IR) test was used to assess the insulin resistance. A fasting insulin test less than $10 \mathrm{IU} / \mathrm{mL}$ was considered optimal. The test was calculated by the following formula: HOMA-IR=(fasting insulin [mU/l]xfasting plasma glucose [mg/ $\mathrm{dL}]) / 405$.

The diagnosis of atherogenic dyslipidemia (AD) required elevated TGC $\geq 150 \mathrm{mg} / \mathrm{dL}$ and low concentrations of HDL-C ( $<40$ $\mathrm{mg} / \mathrm{dL}$ in men and $<50 \mathrm{mg} / \mathrm{dL}$ in women) in a routine lipoprotein profile $(20,21)$.

Postoperative subclinical hypothyroidism is defined as an elevated TSH (above the upper limit of reference range) with nor- mal FT4 and FT3 concentrations. Normal ranges for TSH, FT3, and FT4 were $0.41-4.24 \mathrm{mlU} / \mathrm{mL}, 2.5-3.9 \mathrm{pg} / \mathrm{mL}$, and 0.61-1.06 $\mathrm{ng} / \mathrm{dL}$, respectively.

Peripheral blood samples were obtained after 12 hours of fasting, and low-density lipoprotein (LDL-C), high-density lipoprotein (HDL-C), total cholesterol (TC), triglycerides (TGC), fasting blood glucose (FBG), fasting insulin (FI), thyroid stimulating hormone (TSH), free T3 (FT3), free T4 (FT4), highly sensitive Creactive protein (hsCRP), and hemoglobin A1c ( $\mathrm{HbA1c}$ ) levels were analyzed. Patients were invited to the hospital for 12- and 24-month visits, and the previous steps were repeated. The data and concomitant medication of the patients were recorded.

\section{Laboratory Technology}

A Roche cobas c 311 photometric analyzer was used for the measurement of substrates (albumin, total protein, Urea/Bun), enzymes (ALP, ALT, AST, GGT), the cardiovascular risk profile (TC, HDL-C, LDL-C, TGC), and hsCRP. The UniCel Dxl 800; Beckman CoulterNyon, Switzerland, system was used for the determination of the FT3, FT4, and TSH levels. Applied FT3 and FT4 assays were paramagnetic particles; chemiluminescent immunoassays for the quantitative determination of free thyroxine and T3 levels in human serum and plasma. A hypersensitive $\mathrm{hTSH} /$ fast TSH Reagent (third-generation assay) made up of paramagnetic particles coated with goat anti-mouse lgG/antihTSH MAb complexes was used for the TSH measurement. The analytical sensitivity of the assay was $0.003 \mu \mathrm{lU} / \mathrm{mL}$.

\section{Statistical Analysis}

Data were expressed as the mean \pm standard deviation of the mean. Proportions were compared by $x 2$ analysis. The mean values of two groups (with or without MetS) were compared by the Student's T-test or by a nonparametric test if the data were not normally distributed. Comparisons of parameters with more than 2 groups (preoperative and postoperative 12th and 24th month values) were analyzed by the analysis of variance. Stepwise logistic regression analysis was used to determine independent predictors of MetS. $p<0.05$ was considered statistically significant. All statistical analyses were performed using the SPSS, version 15 (SPSS Inc.; Chicago, IL, USA).

Compared to patients with preexisting MetS before the operation, we assumed a $10 \%$ increase at the end of the 1 st year after total thyroidectomy. Thus, determining the statistical power as 0.8 and alpha error level of $5 \%$, we found that the required number of patients was 136 . In our study, the percentage of patients with metabolic syndrome increased by approximately $12 \%$ in the first year after surgery. However, this analysis was based on 59 patients, and the statistical power was 0.64.

\section{RESULTS}

The mean age of the patients was $51.9 \pm 12.7$ (23-75) years. The mean BMI and the average WC were $28.3 \pm 4.21 \mathrm{~kg} / \mathrm{m}^{2}(20.7-$ 40.7) and $100.2 \pm 10.1(76-123) \mathrm{cm}$. The mean systolic and diastolic BP were $120.2 \pm 11.4 \mathrm{mmHg}(100-150)$ and $76.8 \pm 8.6$ $\mathrm{mmHg}(60-90)$, respectively.

There was a female preponderance $(50$ pts. or $83.3 \%$ for females vs. 9 pts. or $16.6 \%$ for males for MNG). With respect to 
pre-existing (preoperative) co-morbid diseases, 18 patients had hypertension (30.5\%), nine had DM (15.3\%), three had coronary artery disease (5.1\%), and three had hyperlipidemia (5.1\%). Of the hypertensive patients, $8.5 \%$ was on ss-a blocker treatment $(n=5), 15.3 \%$ were using angiotensin-convertingenzyme inhibitors or angiotensin II receptor antagonists $(n=9)$, $8.5 \%$ of them received thiazide diuretics $(n=5)$, and $5.1 \%$ were using calcium-channel blockers $(n=3)$. Seven patients with diabetes were using oral anti-diabetic drugs, and 2 were on insulin treatment.

The mean TSH, FT3, and FT4 values were $1.58 \pm 2.72 \mathrm{mlU} / \mathrm{mL}$ (0.01-19), $3.11 \pm 0.41 \mathrm{pg} / \mathrm{mL}(2.54-4.69)$ and $0.84 \pm 0.16 \mathrm{ng} / \mathrm{dL}$ (0.43-1.30). All but 1 patient had normal FT3 and FT4 values before the operation. A female patient presented with a FT4 level of $1.3 \mathrm{ng} / \mathrm{dL}$ and TSH value of $0.06 \mathrm{mlU} / \mathrm{mL}$.

The indication for surgery was compressive symptoms causing neck discomfort, progressive growth of the dominant nodule or recurrence of cysts after aspiration in all, and additionally nodule(s) suspicious for malignancy in 2 patients. The final pathological diagnosis was MNG in 49 patients (83\%), MNG with micropapillary carcinoma in 8 cases $(13.6 \%)$, and MNG with papillary thyroid carcinoma in 2 (3.4\%) patients. Postoperative replacement therapy with L-thyroxine is not implemented in any case until the final pathology result is obtained. This corresponded to an average period of 2 weeks.
Fifty-seven patients completed the $1^{\text {st }}$ year, and 42 cases already completed the $2^{\text {nd }}$ year controls, and the results were statistically evaluated.

Comparison of Pre-Operative Period vs. Post-Operative $1^{\text {st }}$ Year A preoperative TSH value of $1.58 \pm 2.72 \mu \mathrm{IU} / \mathrm{mL}$ increased to $2.13 \pm 3.64(p=0.06)$, and preoperative FT4 value of $0.84 \pm 0.16$ $\mathrm{ng} / \mathrm{dL}$ improved significantly to $0.99 \pm 0.20 \mathrm{ng} / \mathrm{dL}(\mathrm{p}<0.001)$ during the postoperative 12 months, indicating the adequacy of thyroxine replacement therapy. Indeed, the evaluation of the 12-month laboratory results revealed normal FT4 levels in all cases (Table 1).

Preoperative values of BMI, WC, and the ratio of patients with metabolic syndrome increased significantly statistically during the 1st year after the operation. With respect to BMI, 15 patients (25.4\%) were normal weight, 24 (40.6\%) were overweight, and 20 (34\%) were obese before the operation. At the 1 st year follow-up, the number of patients with normal weight markedly decreased, and the number of obese patients increased (Figure 1).

Similarly, SBP and DBP increased, and the TG and LDL values worsened significantly (Table 1). In addition, 1 patient had newly diagnosed hypertension, and 2 cases manifested with uncontrolled hypertension requiring a second drug. At the first year, 11 patients (19\%) had TSH values higher than nor$\mathrm{mal}$ (>4.24 ml/mL). The comparison of patients with normal

Table 1. Comparison of laboratory and metabolic parameters in patients according to the follow-up period

\begin{tabular}{|c|c|c|c|c|}
\hline & $\begin{array}{l}\text { Pre-operative (N:59) } \\
\quad(\text { Mean } \pm \text { SD) }\end{array}$ & $\begin{array}{l}\text { Post-operative } \\
12 \text { Months (N:58) } \\
\text { (Mean士SD) }\end{array}$ & $\begin{array}{l}\text { Post-operative } \\
24 \text { Months (N:42) } \\
\text { (Mean士SD) }\end{array}$ & $p$ \\
\hline Free T3 (pg/mL) (N:2.5-3.9) & $3.11 \pm 0.40$ & $2.84 \pm 0.32$ & $3.35 \pm 4.42$ & 0.02 \\
\hline Free T4 (ng/dL) (N:0.6-1.1) & $0.84 \pm 0.16$ & $0.99 \pm 0.20$ & $1.02 \pm 0.23$ & $<0.001$ \\
\hline $\mathrm{TSH}(\mathrm{mlU} / \mathrm{mL})(\mathrm{N}: 0.4-4.24)$ & $1.58 \pm 2.72$ & $2.13 \pm 3.64$ & $4.63 \pm 7.46$ & 0.06 \\
\hline Subclinical hypothyroid patient rate (\%) & 10 & 19 & 31 & 0.46 \\
\hline Fasting glucose (mg/dL) & $109 \pm 31$ & $108 \pm 25$ & $109 \pm 28$ & 0.93 \\
\hline HOMA-IR & $3.24 \pm 3.93$ & $2.89 \pm 3.58$ & $3.08 \pm 4.63$ & 0.74 \\
\hline HgbA1c (\%) & $5.8 \pm 0.7$ & $6.0 \pm 0.6$ & $5.8 \pm 0.6$ & 0.4 \\
\hline $\mathrm{hsCRP}(\mathrm{mg} / \mathrm{dL})$ & $2.55 \pm 3.51$ & $0.55 \pm 0.62$ & $2.72 \pm 3.78$ & $<0.001$ \\
\hline Total cholesterol (mg/dL) & $190 \pm 31$ & $208 \pm 36$ & $216 \pm 34$ & 0.179 \\
\hline $\mathrm{HDL}-\mathrm{C}(\mathrm{mg} / \mathrm{dL})$ & $54 \pm 12$ & $53 \pm 11$ & $54 \pm 13$ & 0.37 \\
\hline LDL-C (mg/dL) & $118 \pm 26$ & $139 \pm 28$ & $143 \pm 28$ & 0.002 \\
\hline Triglyceride (mg/dL) & $116 \pm 53$ & $146 \pm 88$ & $149 \pm 77$ & 0.004 \\
\hline Systolic BP (mmHg) & $118 \pm 11$ & $128 \pm 13$ & $130 \pm 12$ & 0.001 \\
\hline Diastolic BP (mmHg) & $75 \pm 8.8$ & $83 \pm 11$ & $80 \pm 10$ & 0.01 \\
\hline Weight (kg) & $75 \pm 12$ & $78 \pm 12$ & $79 \pm 12$ & 0.001 \\
\hline BMI $\left(\mathrm{kg} / \mathrm{m}^{2}\right)$ & $28.2 \pm 4.2$ & $30.0 \pm 4.2$ & $30.3 \pm 4.3$ & 0.001 \\
\hline Waist circumference (mm) & $100 \pm 10$ & $105 \pm 11$ & $106 \pm 11$ & $<0.001$ \\
\hline Obesity (\%) & 34 & 39.7 & 47.7 & 0.78 \\
\hline Metabolic syndrome (\%) & 39 & 51.7 & 61.9 & 0.01 \\
\hline Metabolic syndrome severity score & $0.92 \pm 0.75$ & $0.96 \pm 0.60$ & $1.04 \pm 0.72$ & 0.85 \\
\hline
\end{tabular}

SD: standard deviation; TSH: thyroid stimulanting hormone; HDL-C: high-density lipoproteins cholesterol; LDL-C: low-density lipoprotein cholesterol; BP: blood pressure; BMI: body mass index 


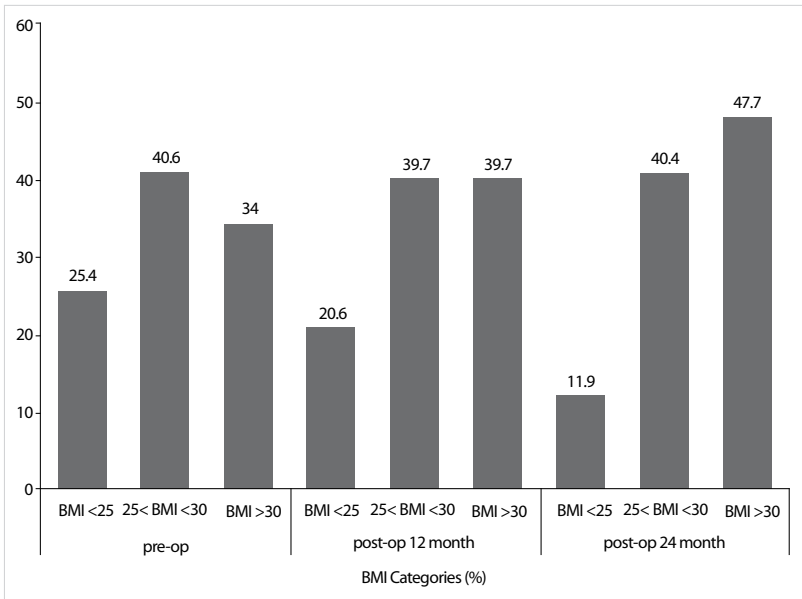

Figure 1. Body mass index (BMI) change over time
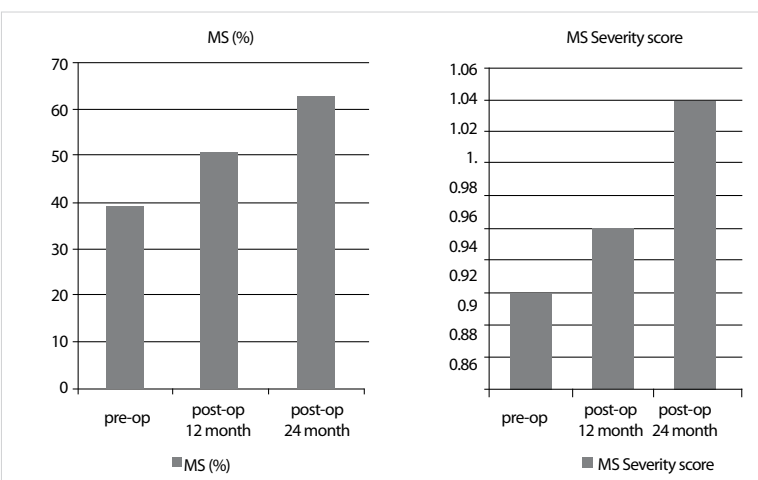

Figure 2. Metabolic syndrome and the severity score change over time

and high TSH levels at 1 year after the operation revealed no statistically significant difference in terms of the proportion of cases with MetS ( $55 \%$ vs. $36 \% ; p=0.265)$, the mean BMI $(30 \pm 5$ vs. $29 \pm 4 ; p=0.44)$, and mean WC $(105 \pm 12 \mathrm{~cm}$ vs. $103 \pm 11 \mathrm{~cm}$; $\mathrm{p}=0.52$ ). At the postoperative first year, the number of patients with MetS was $30(51.7 \%)$ and their MetSSS was $0.96 \pm 0.60$. Seven of them were newly diagnosed MetS (Figure 2).

The metabolic syndrome severity score of patients with former MetS ( 23 pts.) increased from $1.05 \pm 0.76$ to $1.13 \pm 0.67 ; p=0.56$. Compared to other patients, patients with MetS were in elderly, with higher baseline BMI and more often had a history of diabetes and hypertension, but they did not have significant difference with regard to the thyroid function test values (Table 2). Among the variables such as age, gender, the TSH level, basal BMI, history of DM and hypertension; the presence of DM (Exp[B] 14.34; $p=0.03)$ and hypertension (Exp[B] 6.57; $p=0.02$ ) independently associated with the development of MetS in multivariate logistic regression analysis.

\section{Comparison of Pre-Operatıve vs. Post-Operative $2^{\text {nd }}$ Year}

Forty-two patients have completed the 2 nd year after BTT. Of the patients, the mean TSH, FT4, and FT3 values were $4.63 \pm 7.46$ $\mathrm{mlU} / \mathrm{mL}, 1.02 \pm 0.23 \mathrm{ng} / \mathrm{dL}$, and $3.35 \pm 4.42 \mathrm{pg} / \mathrm{mL}$., respectively. The lipid profile and blood pressure parameters deteriorated, and the mean BMI and WC with MetS rates significantly increased at the 2 nd year follow-up of patients (Table 1). The increase in the MetS rates was accompanied by an increase in MetSSS (Figure 2).
Subclinic hypothyroidism was observed in 13 cases (30.9\%) at the $24^{\text {th }}$ month after surgery. Eight of them (61.5\%) had obesity, and 12 (92\%) had MetS. Of the remaining 29 patients with normal TSH values, 12 (41\%) were obese, and 14 (48\%) had developed MetS. The difference between the MetS rates of patients with normal and high TSH levels was statistically significant ( $92 \%$ vs. $48 \% ; p=0.001)$.

Those who had MetS were elderly, often had subclinic hypothyroidism, a higher basal and surveillance $\mathrm{BMI}$, and had more frequently DM and hypertension (Table 2). Among the variables such as age, gender, baseline BMI, the history of DM and hypertension, and the TSH level; the baseline BMI $(\operatorname{Exp}[B] 1.60$; $\mathrm{p}=0.003$ ) independently associated with MetS in multivariate logistic regression analysis was identified.

\section{DISCUSSION}

In this study; despite the LT4 replacement therapy in patients who underwent TT, we observed worsening of metabolic parameters and an increase in the prevalence of MetS during the 2-year follow-up period. Indeed, the incidence of MetS increased from $39 \%$ to $52 \%$ at the postoperative 1 st year and rose up to $62 \%$ at the 2 nd year follow-up with simultaneous increase in MetSSS. Moreover, MetS rate rose to $92 \%$ in patients with the TSH level $>4.2 \mathrm{mIU} / \mathrm{mL}$ at the $2^{\text {nd }}$ year control.

The relationship between thyroid dysfunction and MetS has been shown in several studies. In these patients, the most common thyroid dysfunction is subclinical hypothyroidism (22-24). However, the literature about the frequency of MetS in patients with multinodular goitre is limited. In a study of 1422 Caucasian patients with thyroid disease, the presence of multinodular non-toxic goitre independently predicted the development of MetS (25). In our study, metabolic syndrome was present in $39 \%$ of patients referred for surgery because of MNG. More importantly, we detected a significant increase in the rate and severity of MetS after the operation. This indicates the importance of the choice of operation (total or subtotal thyroidectomy) and a close follow-up in these patients with high cardiovascular risk.

In our study group, we observed a significant increase in the prevalence of MetS at the 1st year follow-up despite the LT-4 replacement therapy. Several factors may be responsible for this process. First of all, keeping the target TSH levels lower for these specific patients can lead to a reduction in the development and progression of MetS. A significant relationship between the prevalence of MetS and the TSH levels existed in a large-scale cohort study including 7270 patients and by offsetting a normal TSH value between 0.35 and $1.38 \mathrm{mIU} / \mathrm{mL}$; the prevalence of MetS increased 1.25-fold in patients with the TSH levels between 2.42 and $3.44 \mathrm{mIU} / \mathrm{mL}$ ), and the MetS risk is increased 1.92-fold in cases with TSH $>4.48 \mathrm{mlU} / \mathrm{mL}$ (26). In our study, the average TSH value at 1 year was in the normal range $(2.13 \pm 3.64 \mathrm{mlU} / \mathrm{mL})$; however, it was higher than the reference TSH value of the previously mentioned study. Relatively high TSH values may contribute to the deterioration of metabolic profile of patients after TT.

Two important features of this study were the progression of central obesity reflected by elevated body weight, BMI, and WC after surgery and the increasing rate of patients with MetS 
Table 2. Comparison of patients with or without metabolic syndrome in three periods

\begin{tabular}{|c|c|c|c|c|c|c|c|c|c|}
\hline & $\begin{array}{c}\text { Pre-op } \\
\text { MS(+) } \\
{[(n: 23), 39 \%]} \\
(M e a n \pm S D)\end{array}$ & $\begin{array}{c}\text { Pre-op } \\
\text { MS(-) } \\
{[(\mathrm{N}: 36), 61 \%]} \\
\text { (Mean } \pm \text { SD) }\end{array}$ & p & $\begin{array}{c}12 \text { months } \\
\text { MS }(+) \\
{[(n: 30), 51.7 \%]} \\
(\text { Mean } \pm \text { SD })\end{array}$ & $\begin{array}{c}12 \text { months } \\
\text { MS }(-) \\
{[(n: 28), 48.3 \%]} \\
\text { (Mean } \pm \text { SD) }\end{array}$ & $\mathbf{P}$ & $\begin{array}{c}24 \text { months } \\
\text { MS (+) } \\
{[(\mathrm{n}: 26), 61.9 \%]} \\
\text { (Mean } \pm \text { SD) }\end{array}$ & $\begin{array}{c}24 \text { months } \\
\text { MS }(-) \\
{[(n: 16), 38.1 \%]} \\
\text { (Mean } \pm \text { SD) }\end{array}$ & $\mathbf{P}$ \\
\hline Age $^{*}$ (years) & $57 \pm 10$ & $49 \pm 13$ & 0.01 & $56 \pm 10$ & $48 \pm 13$ & 0.01 & $58 \pm 10$ & $49 \pm 14$ & 0.02 \\
\hline Gender (female/male) & $19 / 4$ & $31 / 5$ & 0.72 & $26 / 4$ & $23 / 5$ & 0.64 & $23 / 3$ & $13 / 3$ & 0.52 \\
\hline $\mathrm{BMI}^{*}\left(\mathrm{~kg} / \mathrm{m}^{2}\right)$ (basal) & $30.5 \pm 4.3$ & $26.8 \pm 3.5$ & 0.001 & $29.8 \pm 3.96$ & $26.7 \pm 3.78$ & 0.004 & $30.9 \pm 3.89$ & $25.7 \pm 3.10$ & $<0.001$ \\
\hline $\mathrm{BMI}^{*}\left(\mathrm{~kg} / \mathrm{m}^{2}\right)$ (Last control) & & & & $30.6 \pm 4.13$ & $27.5 \pm 3.88$ & 0.005 & $31.9 \pm 3.8$ & $27.1 \pm 4.0$ & $<0.001$ \\
\hline Obesity" (basal) & $11(47.8)$ & $9(25)$ & 0.08 & $13(43)$ & $7(25)$ & 0.14 & $16(62)$ & 2(13) & 0.001 \\
\hline Obesity" (Last control) & & & & 14(46.6) & $9(32)$ & 0.26 & $17(65)$ & $3(19)$ & 0.002 \\
\hline Hypertansion" & $14(60.5)$ & $4(11,1)$ & $<0,001$ & $16(53)$ & $3(11)$ & 0.001 & $12(46)$ & $2(12.5)$ & 0.01 \\
\hline Hyperlipidemia" & $3(11.5)$ & $0(0)$ & 0.08 & 10(33.3) & $0(0)$ & 0.08 & $3(11.5)$ & $0(0)$ & 0.08 \\
\hline Diabetes" & $6(26)$ & $3(8.3)$ & 0.09 & $8(27)$ & 1(4) & 0.01 & $8(30.7)$ & $1(6.2)$ & 0.03 \\
\hline HOMA-IR* & 4. $20 \pm 5.69$ & $2.45 \pm 3.61$ & 0.154 & $3.91 \pm 5.42$ & $2.37 \pm 3.46$ & 0.20 & $3.82 \pm 4.33$ & $1.60 \pm 0.61$ & 0.08 \\
\hline Fasting Glucose* (mg/dL) & $116 \pm 31$ & $99 \pm 23$ & 0.01 & $114 \pm 31$ & $98 \pm 20$ & 0.02 & $116 \pm 33$ & $97 \pm 9.4$ & 0.009 \\
\hline $\left.\operatorname{HbA1c} c^{*} \%\right)$ & $6.08 \pm 0.87$ & $5.62 \pm 0.68$ & 0.02 & $6.0 \pm 0.7$ & $5.5 \pm 0.3$ & 0.01 & $5.97 \pm 0.62$ & $5.39 \pm 0.41$ & 0.002 \\
\hline $\mathrm{HsCRP*}(\mathrm{mg} / \mathrm{dL})$ & $1.36 \pm 1.99$ & $1.81 \pm 3.16$ & 0.546 & $2.20 \pm 3.50$ & $1.08 \pm 1.53$ & 0.12 & $2.56 \pm 3.12$ & $3.20 \pm 3.58$ & 0.54 \\
\hline $\mathrm{FT}^{*}(\mathrm{pg} / \mathrm{mL})$ & $2.98 \pm 0.30$ & $3.18 \pm 0.44$ & 0.06 & $2.89 \pm 0.35$ & $2.91 \pm 0.31$ & 0.12 & $3.70 \pm 5.55$ & $2.73 \pm 0.51$ & 0.49 \\
\hline $\mathrm{FT} 4^{*}(\mathrm{ng} / \mathrm{dL})$ & $0.86 \pm 0.18$ & $0.81 \pm 0.13$ & 0.25 & $1.05 \pm 0.21$ & $0.93 \pm 0.16$ & 0.19 & $1.01 \pm 0.27$ & $1.03 \pm 0.17$ & 0.78 \\
\hline $\mathrm{TSH}^{*}(\mathrm{mlU} / \mathrm{mL})$ & $2.22 \pm 3.97$ & $1.10 \pm 1.21$ & 0.20 & $1.95 \pm 3.03$ & $4.78 \pm 1.95$ & 0.10 & $6.59 \pm 8.54$ & $1.36 \pm 2.97$ & 0.007 \\
\hline Hypothyroid Patients Rate & $e^{\#} 3(11.5)$ & $3(8.3)$ & 0.56 & $4(13)$ & $7(25)$ & 0.27 & $12(46)$ & $1(6)$ & 0.002 \\
\hline
\end{tabular}

Pre-op: preoperative; MS: metabolic syndrome; SD: standard deviation; FT3: free-T3; FT4: free-T4;

TSH: thyroid stimulanting hormone; BMI: body mass index

Datas are presented as *;mean \pm SD \#; $\mathrm{n}(\%)$

(from $39 \%$ to $51.7 \%$ ) at the postoperative 1 st year (Table 1 ). The FT3 levels significantly decreased within the 1 st year following the operation but improved thereafter. In our opinion, the most rationalistic explanation of the increase in WC appears to be diminished 3.3'-triiodothyronine-responsive energy expenditure and corresponding slow basal metabolic rate in these patients with the FT3 hormone levels within the lower limit of normal value $(27,28)$. It is very-well known that thyroid hormones affect the synthesis and particularly the degradation of lipids. Thus, both the utilization of lipid substrates and the mobilization of triglycerides stored in the adipose tissue should be reduced in these patients (29). Lipid disorders in our series were consistent with a Colorado study, which was reflected by the increased mean total cholesterol and low-density lipoprotein cholesterol levels. In the Colorado study, impaired lipid profile was observed particularly in subjects with subclinical hypothyroidism (TSH values between 5.1 and $10 \mathrm{mlU} / \mathrm{L}$ ); however, in our study, a progressively deteriorating TC and LDL profile was present in the clear majority of patients independently from the TSH levels (30). Similarly, in a separate study, total thyroidectomy seriously deteriorated the lipid profile. By an effective thyroxine replacement, the patients have become euthyroid at least for 3 months after TT. However, compared with the the preoperative serum total cholesterol levels, the deteriorated TC values after TT remained unchanged at the 6th month follow-up (31). What measures to be taken to counteract the cardiometabolic adverse effects of impaired lipid profile and increased (W, BMI, WC) is a matter of concern in TT patients. increased risk of the coronary heart disease mortality has been shown particularly in those with a TSH level of $10 \mathrm{mIU} / \mathrm{L}$ or greater (32). None of the patients with hypertension and coronary heart disease required cardiac intervention or experienced myocardial infarction in our series. This may be attributed to shorter follow-up despite a high (31\%) prevalance of subclinic hypothyroidism ( 13 cases at the $24^{\text {th }}$ month after TT).

This study provides important data of various biochemical parameters and body composition and their effects in patients undergoing TT. However, it lacks a control group in terms of an optimal medical treatment after surgery; therefore, a controlled study is necessary to confirm our hypothesis that TT renders patients to metabolic complications that could not be managed by the levothyroxine treatment alone. This analysis is based on 59 patients, and the statistical power is 0.64 . Although the statistical power is low, our results were noteworthy that especially preoperative BMI was statistically significant in predicting the postoperative MetS.

\section{CONCLUSION}

MetS is a major problem in adult patients with non-toxic multinodular goiter undergoing surgery. In these patients, an increased frequency of MetS can be observed even after the administration of levothyroxine replacement therapy following TT. Given the increased frequency of MetS after surgery in patients with preexisting DM, hypertension, and high $\mathrm{BMI}$, if possible, a subtotal thyroidectomy and/or alternative thyroid replacement therapy may be considered. 
Ethics Committee Approval: Authors declared that the research was conducted according to the principles of the World Medical Association Declaration of Helsinki "Ethical Principles for Medical Research Involving Human Subjects" (amended in October 2013).

Informed Consent: Written informed consent was obtained from patients who participated in this study.

Peer-review: Externally peer-reviewed.

Author Contributions: Concept - I.Z., A.U.; Design - A.U.; Supervision V.S., A.U.; Materials - B.Z., G.O.; Data Collection and/or Processing - B.Z., G.O., A.A.; Analysis and/or Interpretation - A.D. E.T.; Literature Search - E.T., A.U.; Writing Manuscript - I.Z., A.U., E.T.; Critical Reviews - V.S., E.T.

Conflict of Interest: The authors have no conflicts of interest to declare.

Financial Disclosure: The authors declared that this study has received no financial support.

\section{REFERENCES}

1. FASTSTATS - Inpatient Surgery. Available from: http://www.cdc. gov/nchs/fastats/insurg.htm

2. Barczyński M, Konturek A, Stopa M, Cichoń S, Richter P, Nowak W. Total thyroidectomy for benign thyroid disease: is it really worthwhile? Ann Surg 2011; 254: 724-729. [CrossRef]

3. Tezelman S, Borucu I, Senyurek Giles Y, Tunca F, Terzioglu T. The change in surgical practice from subtotal to near-total or total thyroidectomy in the treatment of patients with benign multinodular goiter. World J Surg 2009 33: 400-405. [CrossRef]

4. Musholt TJ. Total thyroidectomy for multinodular goiter. Chirurg 2010 81: 603-606, 608-611. [CrossRef]

5. Rayes N, Steinmüller T, Schröder S, Klötzler A, Bertram H, Denecke $T$, et al. Bilateral subtotal thyroidectomy versus hemithyroidectomy plus subtotal resection (Dunhill procedure) for benign goiter: long-term results of a prospective, randomized study. World J Surg 2013; 37: 84-90. [CrossRef]

6. Sancho JJ, Prieto R, Due-as JP, Ribera C, Ripollés J, Larrad A, et al. $A$ randomized trial of hemithyroidectomy versus Dunhill for the surgical management of asymmetrical multinodular goiter. Ann Surg 2012; 256: 846-851. [CrossRef]

7. Bernal J, Refetoff S. The action of thyroid hormone. Clin Endocrinol (Oxf) 1977; 6: 227-249. [CrossRef]

8. Pucci E, Chiovato L, Pinchera A. Thyroid and lipid metabolism. Int J Obes Relat Metab Disord 2000; 24 Suppl 2: 109-112. [CrossRef]

9. Kim B. Thyroid hormone as a determinant of energy expenditure and the basal metabolic rate. Thyroid 2008; 18: 141-144. [CrossRef]

10. Klein I, Ojamaa K. Thyroid hormone targeting the vascular smooth muscle cell. Circ Res 2001; 88: 260-261. [CrossRef]

11. Pearce EN. Update in lipid alterations in subclinical hypothyroidism. J Clin Endocrinol Metab 2012; 97: 326-333. [CrossRef]

12. Duntas LH. Thyroid disease and lipids. Thyroid 2002; 12: 287-293. [CrossRef]

13. Poyrazoglu S, Bas F, Darendeliler F. Metabolic syndrome in young people. Curr Opin Endocrinol Diabetes Obes 2014; 21: 56-63. [CrossRef]

14. Hu G, Qiao Q, Tuomilehto J, Balkau B, Borch-Johnsen K, Pyorala K; DECODE Study Group. Prevalence of the metabolic syndrome and its relation to all-cause and cardiovascular mortality in nondiabetic European men and women. Arch Intern Med 2004; 164: 1066-1076. [CrossRef]

15. Iwen KA, Schröder E, Brabant G. Thyroid hormones and the metabolic syndrome. Eur Thyroid J 2013; 2: 83-92. [CrossRef]
16. Expert Panel on Detection, Evaluation, and Treatment of High Blood Cholesterol in Adults. Executive summary of the third report of the National Cholesterol Education Program (NCEP) Expert Panel on Detection, Evaluation, and Treatment of High Blood Cholesterol in Adults (Adult Treatment Panel III). JAMA 2001; 285: 2486-2497. [CrossRef]

17. Gurka MJ, Lilly CL, Oliver MN, DeBoer MD. An examination of sex and racial/ethnic differences in the metabolic syndrome among adults: a confirmatory factor analysis and a resulting continuous severity score. Metabolism 2014; 63: 218-225. [CrossRef]

18. Chobanian AV, Bakris GL, Black HR, Cushman WC, Green LA, Izzo JL Jr, et al. The Seventh Report of the Joint National Committee on Prevention, Detection, Evaluation and Treatment of High Blood Pressure: the JNC 7 report. JAMA 2003; 289: 2560-2572. [CrossRef]

19. American Diabetes Association. Standards of medical care in diabetes-2013. Diabetes Care 2013; 36: 11-66. [CrossRef]

20. National Cholesterol Education Program (NCEP) Expert Panel on Detection, Evaluation, and Treatment of High Blood Cholesterol in Adults (Adult Treatment Panel III).Third report of the National Cholesterol Education Program (NCEP) expert panel on detection, evaluation, and treatment of high blood cholesterol in adults (Adult Treatment Panel III). Final report. Circulation 2002; 106: 3143-3421.

21. Quispe R, Manalac RJ, Faridi KF, Blaha MJ, Toth PP, Kulkarni KR, et al. Relationship of the triglyceride to high-density lipoprotein cholesterol (TG/HDL-C) ratio to the remainder of the lipid profile: The Very Large Database of Lipids-4 (VLDL-4) study. Atherosclerosis 2015; 242: 243-250. [CrossRef]

22. Meher LK, Raveendranathan SK, Kota SK, Sarangi J, Jali SN. Prevalence of hypothyroidism in patients with metabolic syndrome. Thyroid Res Pract 2013; 10: 60-64. [CrossRef]

23. Lai CC, Tang SH, Pei D, Lai CC, Chen YL, Wu CZ, et al. The prevalence of subclinical thyroid dysfunction and its association with metabolic syndrome in Taiwanese elderly. Int J Gerontol 2011; 5: 25-29. [CrossRef]

24. Uzunlulu M, Yorulmaz E, Oguz A. Prevalence of subclinical hypothyroidism in patients with metabolic syndrome. Endocr J 2007; 54: 71-76. [CrossRef]

25. Rendina D, De Filippo G, Mossetti G, Zampa G, Muscariello R, Benvenuto $G$, et al. Relationship between metabolic syndrome and multinodular non-toxic goiter in an inpatient population from a geographic area with moderate iodine deficiency. J Endocrinol Invest 2012; 35: 407-412.

26. Lee YK, Kim JE, Oh HJ, Park KS, Kim SK, Park SW, et al. Serum TSH level in healthy Koreans and the association of TSH with serum lipid concentration and metabolic syndrome. Korean J Intern Med 2011; 26: 432-439. [CrossRef]

27. Kim B. Thyroid hormone as a determinant of energy expenditure and the basal metabolic rate. Thyroid 2008; 18: 141-144. [CrossRef]

28. Weetman AP. Whose thyroid hormone replacement is it anyway? Clin Endocrinol (Oxf) 2006; 64: 231-233. [CrossRef]

29. Pucci E, Chiovato L, Pinchera A. Thyroid and lipid metabolism. Int J Obes Relat Metab Disord 2000; 24 Suppl 2: 109-112. [CrossRef]

30. Canaris GJ, Manowitz NR, Mayor G, Ridgway EC. The Colorado thyroid disease prevalence study. Arch Intern Med 2000; 160: 526-534. [CrossRef]

31. Erbil Y,Özbey N, Giriş M, Salmaslıoğlu A, Özarmağan S, Tezelman $\mathrm{S}$. Effects of thyroxine replacement on lipid profile and endothelial function after thyroidectomy. Br J Surg 2007; 94: 1485-1490. [CrossRef]

32. Rodondi N, den Elzen WP, Bauer DC, Cappola AR, Razvi S, Walsh JP, et al, for the Thyroid Studies. Subclinical Hypothyroidism and the Risk of Coronary Heart Disease and Mortality. JAMA 2010; 304: 1365-1374. [CrossRef] 